\title{
Dynamics of vitellogenin gene expression at different stages of reproduction in the giant freshwater prawn, Macrobrachium rosenbergii
}

\author{
VIDYA JAYASANKAR, ${ }^{1}$ SAFIAH JASMANI, NAOAKI TSUTSUI, ${ }^{2}$ TSUYOSHI OHIRA, ${ }^{2}$ HISAKO SAIDO- \\ SAKANAKA, ${ }^{1}$ WEI-JUN YANG, ${ }^{1}$ ATSURO OKUNO, ${ }^{1}$ KATSUMI AIDA, ${ }^{2}$ AND MARCY WILDER ${ }^{1}$ \\ 'Japan International Research Center for Agricultural Sciences, Tsukuba, Ibaraki 305-8686, Japan \\ (vidya@jircas.affrc.go.jp), and ${ }^{2}$ Graduate School of Agricultural and Life Sciences, The University of Tokyo, \\ Bunkyo, Tokyo 113-8657, Japan
}

KEY WORDS: hepatopancreas, Macrobrachium rosenbergii, ovary, real-time quantitative PCR, vitellogenin-mRNA

\section{INTRODUCTION}

Vitellogenesis is the process by which yolk proteins or vitellins are synthesized from precursor molecules called vitellogenin $(\mathrm{Vg})$, processed, and finally sequestered by the ovary. Crustacean vitellogenesis is regulated by a variety of neurohormones among which vitellogenesis inhibiting hormone (VIH) produced by the $\mathrm{X}$-organ sinus gland complex located in the eyestalks is an important factor inhibiting

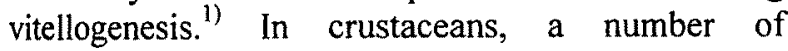
vitellogenin synthetic sites have been identified, including the ovary, hepatopancreas and adipose tissue. $^{2,3,4)}$ In Macrobrachium rosenbergii, the hepatopancreas has been determined to be the principal site of vitellogenin mRNA expression. ${ }^{5)}$ The objective of this study was to obtain a complete view of the dynamics of $\mathrm{Vg}$ synthesis during ovarian maturation and also to examine the effects of eyestalk ablation on the pattern of $\mathrm{Vg}$ mRNA expression. This was done by quantifying $\mathrm{Vg}$ mRNA in hepatopancreas of intact and eyestalk ablated animals at different stages of reproduction using real-time quantitative PCR.

\section{MATERIALS AND METHODS}

Adult Macrobrachium rosenbergii were procured from a commercial source in China. Female prawns weighing 15-25 $\mathrm{g}$ were selected for the experiment and divided into 2 groups, intact and eyestalk ablated. The day on which the animal molted was designated as day -1 and the day following molting as day 0 . In the second group of animals, bilateral eyestalk ablation was performed on day 0 to induce vitellogenesis. Five intact animals each were sacrificed and samples of hepatopancreas and ovary collected on days $-1,0,2,4,8,12,16$ and 24 . In the case of the eyestalk ablated group, 5 animals each were sampled on days $2,4,8,12,16$ and 24 . The gonadosomatic index (GSI) of each individual was also calculated as gonad weight in $\mathrm{g} \mathrm{x} \mathrm{100/body}$ weight in $\mathrm{g}$.

Total RNA was extracted from hepatopancreas and ovary tissue samples using an ISOGEN kit and RNA concentrations were determined spectrophotometrically. Quantification of $\mathrm{Vg}$ mRNA in the samples was done by real-time fluorescence monitoring of PCR amplification product formation on the basis of the Taqman system, using a PE Applied Biosystems Model 7700 sequence detector. A pair of PCR primers to amplify a 105-bp fragment of the $\mathrm{Vg}$ gene and a fluorogenic probe (Taqman probe) were selected from the open reading frame (ORF) of the $\mathrm{Vg}$ cDNA. A reaction mixture containing forward and reverse primers, Taqman probe, buffer optimized for reverse transcription and PCR amplification, and an enzyme mixture of RTase and DNA polymerase was used for the assay. Hepatopancreas sample from an eyestalk ablated individual at the 8 day stage was used as a reference standard. A standard curve generated by measuring gene expression with serial dilutions of this sample was used for relative comparison of the other samples.

\section{RESULTS}

Ovarian maturation was traced in intact and eyestalk ablated animals by examining the GSI of animals at different molt stages. In intact animals the GSI was seen to be between $0.3-0.5 \%$ up to day 8 and started increasing steadily after day 12 . GSI reached a maximum of $5.14 \%$ at 24 days, prior to the next molt. 
In eyestalk ablated animals however, GSI started increasing much earlier, 4 days after molting (1.03\%), and was highest at 16 days $(8.86 \%)$, around the time of the next molt. Subsequent to this, GSI decreased to a minimum of $1.01 \%$ at 20 days, before increasing again.

Relative levels of Vg mRNA in hepatopancreas and ovaries of intact and eyestalk ablated animals were measured. In the hepatopancreas of intact females, relative $\mathrm{Vg}$ mRNA levels were low at 4,378 on day 4 , when the GSI was $0.4 \%$. Around 12 days after the first molt $\mathrm{Vg}$ mRNA expression started increasing, paralleling changes in GSI. Highest levels of $\mathrm{Vg}$ mRNA $(417,131)$ were observed at 24 days, just prior to the next molt. Eyestalk ablation resulted in accelerated rate of $\mathrm{Vg}$ synthesis. In these animals $\mathrm{Vg}$ mRNA expression began to increase as early as 4 days after molting. The highest levels of $\mathrm{Vg} \mathrm{mRNA}$ expression $(374,000)$ were observed around 8-12 days after molting, after which they decreased steadily, with expression reaching a minimum of 28,500 at 20 days. In the ovary of both intact and eyestalk ablated animals, very low levels of $\mathrm{Vg}$ mRNA expression were observed.

\section{DISCUSSION}

A real-time PCR assay was used for quantifying and comparing $\mathrm{Vg}$ mRNA concentrations in hepatopancreas and ovary of $M$. rosenbergii during ovarian maturation in intact and eyestalk ablated animals. Increases in $\mathrm{Vg}$ mRNA expression in the hepatopancreas paralleled changes in GSI showing that the expression of $\mathrm{Vg}$ mRNA is correlated to ovarian maturation. Eyestalk ablation accelerated both ovarian maturation and the rate of $\mathrm{Vg}$ synthesis, but did not affect the overall pattern of $\mathrm{Vg}$ gene expression. The results of this study also cofirm that the hepatopancreas is the principal site of $\mathrm{Vg}$ synthesis in $M$. rosenbergii, with the ovary being only a minor contributor.

\section{REFERENCES}

1. Soyez D, Van Deijnen JE, Martin M. Immunochemical and immunocytochemical studies of the crustacean vitellogenesis-inhibiting hormone (VIH). J. Exp. Zool. 1987; 244: 479-484.

2. Yano I, Chinzei Y. Ovary is the site of vitellogenin synthesis in kuruma prawn, Penaeus japonicus. Comp. Biochem. Physiol. 1987; 86B: 213-218.

3. Soroka Y, Milner Y, Sagi A. The hepatopancreas as a site of yolk protein synthesis in the prawn Macrobrachium rosenbergii. Invert. Reprod. Develop. 2000; 37: 61-68.

4. Tom M, Goren M, Ovadia M. Localization of the vitellin and its possible precursors in various organs of Parapenaeus longirostris (Crustacea, Decapoda, Penaeidae). Int. J. Invert. Reprod. Dev. 1987; 12: 1-12.

5. Yang WJ, Ohira $T$, Tsutsui $N$, Subramoniam T, Huong DTT, Aida K, Wilder MN. Determination of amino acid sequence and site of mRNA expression of four vitellins in the giant freshwater prawn Macrobrachium rosenbergii. J. Exp. Zool. 2000; 287: 413-422. 